\title{
Analysis of The Economic Behavior of Society E- Commerce as An Impact on The Development of The 4.0 Industrial Revolution and Society 5.0
}

\author{
Dito Aditia Darma Nasution ${ }^{1 *}$, Iskandar Muda $^{2}$, Aried Sumekar ${ }^{3}$, Erwin Abubakar \\ ${ }^{1,2,3,4}$ Faculty of Economics and Business, Universitas Sumatera Utara, Medan, Indonesia \\ *ditoaditia@dosen.pancabudi.ac.id
}

\begin{abstract}
Technology is one of the tools to facilitate work. The development of technology has now become a thing that is a major human need in completing work. The development of technology began with the Industrial Revolution 1.0 to the Industrial Revolution 4.0. Besides, changes in human behavior are also marked by the development of Society 5.0. The impact of technological development greatly affects the behavior of the Economic Community especially on e-commerce activities. The development of ecommerce is very dominating in Indonesia. As of March 2019, Indonesia had 30 million people who became e-commerce actors. Based on the results of a survey of 67 respondents in the scope of the University of Pembangunan Panca Budi with an average age of $19-34$ years produced $43.3 \%$ of respondents chose e-commerce with convenience obtained when dealing with e-commerce. Besides, $56.7 \%$ of respondents prefer shopping online compared to conventional shopping systems. Based on the results of the survey, the behavior of the economic community through e-commerce in Indonesia was very dominant in the era of Society 5.0 because people expect ease in meeting their needs.
\end{abstract}

Keywords: The Economy of Society 5.0; E-Commerce; Industrial Revolution 4.0; Behavioral Economics

\section{Introduction}

Societal behavior is currently heavily influenced by the development of technology. The development of technology characterized by the Industrial Revolution 1.0 up to the 4.0 Industrial Revolution is currently one of the factors affecting the behavior of people's lives. In research [1] conducted a social study that occurred in the 4.0 Industrial Revolution, resulted in an assumption that the industrial revolution is not only to interrupt the field of technology but penetrated in the social, economic and legal areas and to address the disruption of the impact of the industrial revolution, it is necessary that the humanities study to regulate the technological developments in order not to exit the prevailing humanitarian norms [2].

Changes in the behavior of people who follow the development of technology and centered on human needs today are better known as the term Society 5.0. In the Society ERA 5.0 every setting of community needs will be human-centered And based on technology developed by the Japanese. The development of Society 5.0 has begun since civilization in the world began [3]. It is characterized by every public behavior centered on the needs of the community. Society 1.0 is characterized by hunting activities to meet the needs of people's life. Society 2.0 
The community familiar with planting in fulfilling the needs of life [4]. In Society, 3.0 people are getting to know and deepen the world of an industry that is believed to facilitate every activity to meet the needs of [5]. Technology began to be applied and used in fulfilling the needs of life and obtaining information in Society 4.0 [6].

In the Society ERA 5.0 every life behavior will be translated with artificial intelligence then will be transformed with millions of data over the Internet [7]. The results of the translation will be dedicated to a new wisdom that will improve human capacity to open up opportunities for humanity [8]. One of the things that affect the behavior of people's lives is the change in economic flows globally [9]. Indonesia's current economic existence has been dissolved in global economic conditions, affecting Indonesia's economy in case of rising or decreasing global economic conditions [10].

The 4.0 Industrial Revolution has presented a wide range of technological developments to facilitate all activities. While Society 5.0 promises a variety of human facilities to meet the needs of life. This has been evident in Indonesian society [11]. The presence of various companies that provide services online-based goods and services have been widespread in Indonesia. One example is the presence of GO-JEK that started as an online transformation service provider has shifted the motorcycle taxi that provides conventional services [12].

The behavior of the Economic community who prefer the online system to ease in fulfilling all aspects of life demands businesses compete to determine the best strategy for competitive advantage [13]. small and medium-sized enterprises (SMEs) which is one of the flagship industries in Indonesia must change business strategy by utilizing technology not to lag with other business people. E-commerce technology is developed to facilitate business transactions by utilizing the internet and website technologies. Based on the survey [14] The magnitude of the population of Indonesia is a big market opportunity for industry actors, it is characterized by 30 million population of Indonesians who become consumers as well as ecommerce actors [15]. Many factors are the reason for the public to change attitudes to meet the needs of life by e-commerce. One of the reasons is the ease of doing transactions offered with e-commerce [16]. In addition to the rapid development of e-commerce in Indonesia is also influenced by the lifestyle of the Millennial people who prefer to shop online [17].

One of the largest millennials is a society with teenagers, especially students. This article focuses on the survey of Community behavior, especially the millennial community in which this is the student/I at the University of Development of Panca Budi as an e-commerce performer. By conducting a survey of the behavioral Economic Community on e-commerce can be assessed how big the role of e-commerce in influencing the behavior of the Economic Community at the University of Pembangunan Panca Budi.

\section{Methodology}

Based on the research characteristics [18] There is a type of research used in this research is a quantitative research type. The quantitative research method is a study based on the philosophy of positivism, used for researching certain populations or samples, in general, sampling techniques done in random, data collection using research instruments, quantitative data analysis/statistics [19]. This type of quantitative study is used because it can provide a fundamental link between empirical observations and mathematical expressions of quantitative relationships [20]. Quantitative research is many studies, ranging from data collection, interpretation of data, and the appearance of the results [14]. 
This study resulted in data from surveys conducted to many respondents. Assessments are conducted to understand how the role of e-commerce technology affects lifestyle and dependence on technology to meet and facilitate the needs of life. The Survey was conducted on 67 respondents with an average age of 18 years up to 34 years.

\section{Result and discussion}

The term development of technology at this time is more often known by the era of Industrial Revolution 4.0. This development is characterized by the development of technology and information as one of the tools used by humans in doing work [21]. The development of the industrial world has begun since the era of the Industrial Revolution 1.0 until now that is still in the era of the Industrial Revolution 4.0. As for the series on the development of the Industrial Revolution era as shown in Figure 1.

In January 2019, Japan launched a roadmap on human needs behavior known as Society 5.0. If the Industrial Revolution discusses how industry existence can make it easier for people to do all activities, Other than the Society 5.0 that is more human-focused not only as an object but also plays an active role in achieving the objectives. The development of Society 5.0 can be seen in Figure 2.

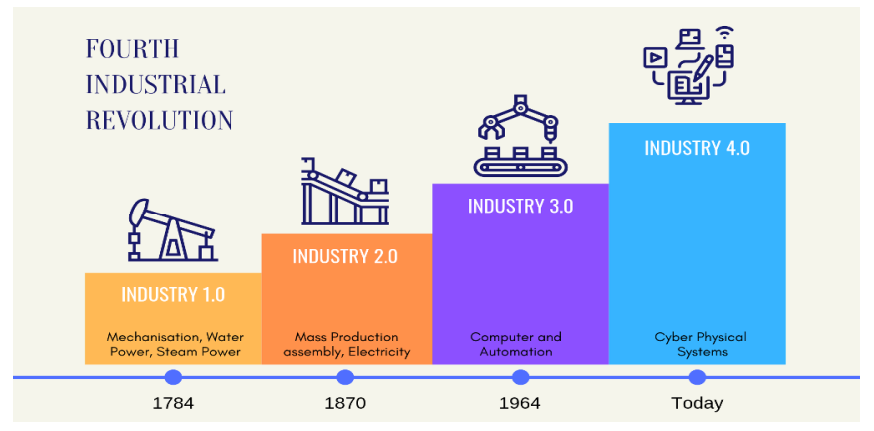

Figure 1. The development of the industrial revolution.

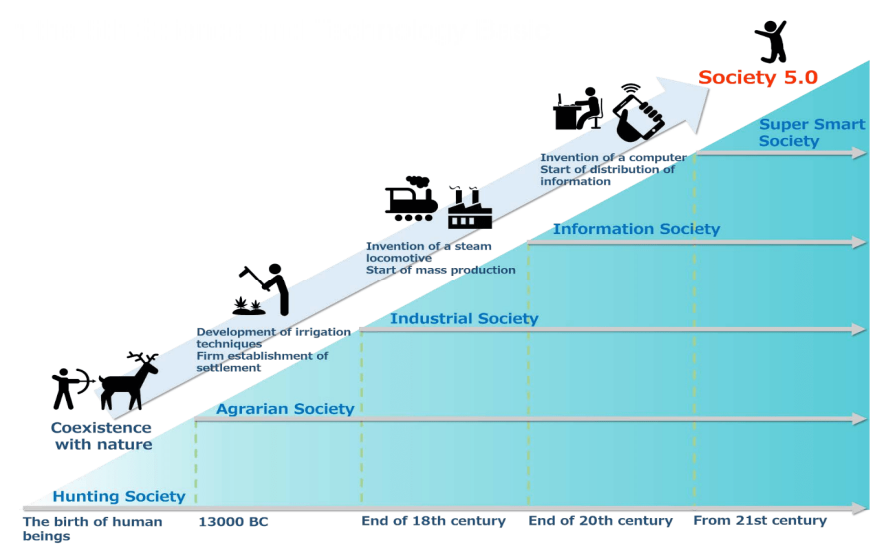

Figure 2. Development of the society. 
In the Society ERA, 5.0 technology and information are not the focus of human life movements. In this era human beings will be an object of innovation, where technology and information will be equipped with big data processing and artificial intelligence that will facilitate every human need. One of the biggest impacts is on changes in social and economic behavior.

The behavioral changes of the economic Community from the impact of the Industrial Revolution 4.0 have been seen with the emergence of e-commerce actors in Indonesia. The development map of 7 major e-commerce in Indonesia is in Figure 3.

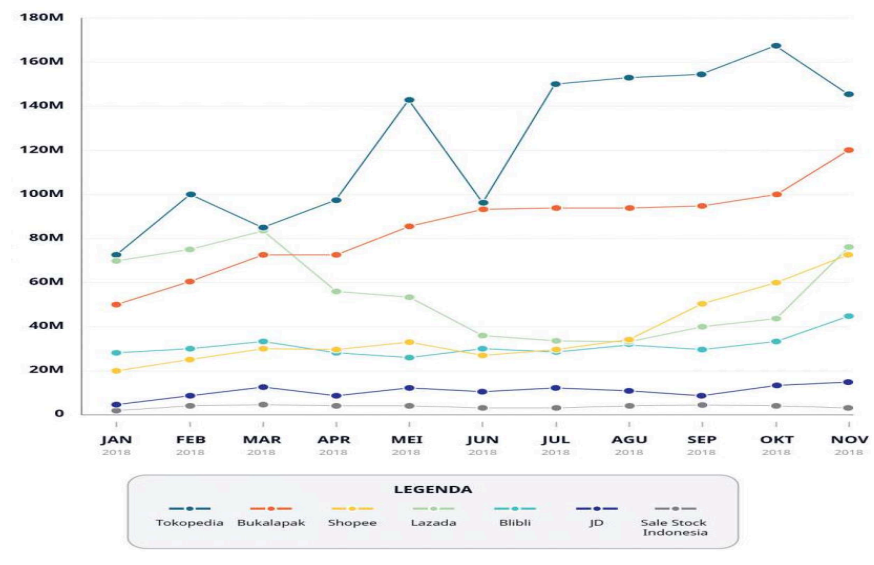

Figure 3. E-commerce web development map.

The development of e-commerce is not separated from the role of technological developments and changes in people's behavior in fulfilling life. According to (Anggraini, 2017) There are 5 e-commerce calcification:

1. Classifieds

The business model is in the form of classified ads that are displayed on the media and only suitable for business people who want to make a sale on a un continuous basis.

2. Marketplace $\mathrm{C} 2 \mathrm{C}$ (customer to customer).

Business Model that brings together the Customer with the role of the third party or often referred to as escrow

3. Shopping mall.

This business Model applies to business people with reputable brands only.

4. Online shop B2C (business to customer)

This business model is very simple, with only sellers who promote their wares through the website and sell them themselves online.

5. Online store social media

This business model leverages the role of social media in promoting media for their products.

E-commerce Developments besides offering a wide range of conveniences also have a negative impact. A transaction system that does not allow a meeting between the seller and the buyer can bring about different risk perceptions to each person. Besides, the inconsistency of the images with the received items sometimes elicits a sense of dissatisfaction with the buyer. But the current economic community is more prioritize the ease of dealing with e-commerce than in considering the losses that will be borne. To see how e-commerce is known by the 
community, Dissemination of the questionnaire given to 67 respondents. According to her gender, $65.7 \%$ is female and $34.3 \%$ male can be seen in Figure 4 . The respondents ' age varies from 18 years to 34 years with the largest number of 19-year-old respondents, $20.9 \%$.

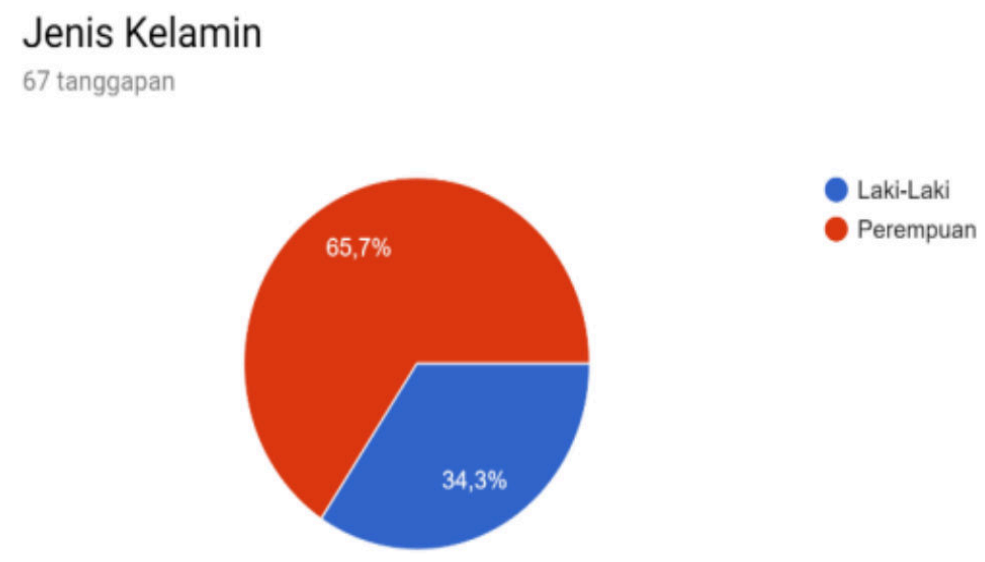

Figure 4. Percentage of gender respondents.

Based on Figure 4 showing the gender percentage of the respondent, indicating the respondent with female gender more dominates the change in economic behavior by ecommerce.

\section{Usia}

67 tanggapan

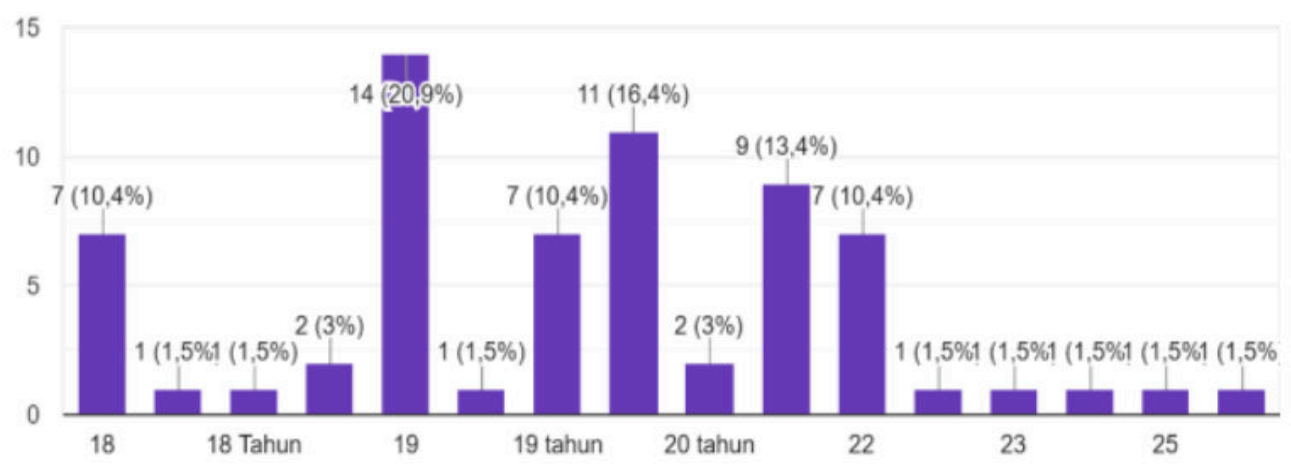

Figure 5. The rrespondents age percentage.

Based on Figure 5 shows the percentage of e-commerce actors more dominated by the Economic community at the age of 19 years. This shows that businesses at that age are more fond of online transactions than on social media. 
Of all the respondents who received the questionnaire, only $26.9 \%$ obtained results that were very knowledgeable about e-commerce. Currently in Indonesia developing e-commerce is quite rapidly in various needs, such as fashion, transportation services, food, and so on. Based on the results of the survey, it is known that top-five e-commerce known respondents are Shopee, Traveloka, Bukalapak, Lazada, and Tokopedia. In addition to knowing about ecommerce, as many as $77.6 \%$ of respondents have been trading in top-five e-commerce. The requirements are varied, and the largest percentage is fashion, books, and electronic equipment.

In Figure 6 below, it is obvious that business people with e-commerce are more pleased with fashion with a percentage value of $46.3 \%$ with 31 respondents.

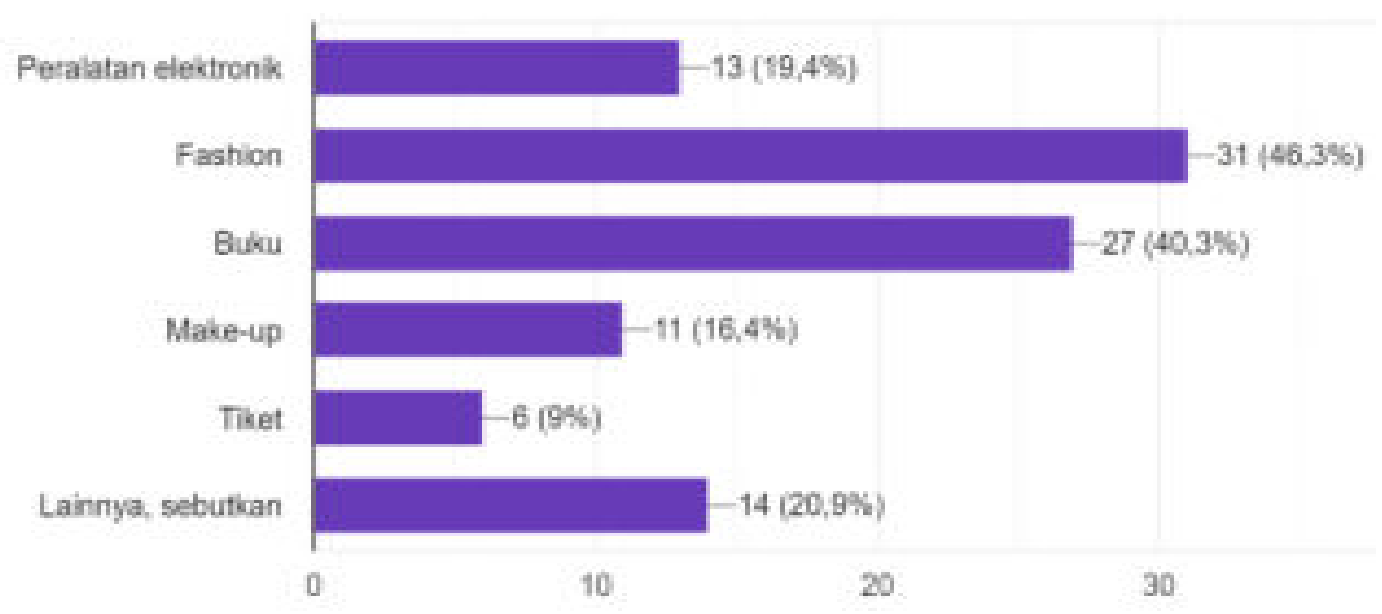

Figure 6. Graph of e-commerce category frequented by public.

Conventional trading switching to online systems is not separated from the various facilities offered by e-commerce. Based on the results of the survey, ease of trading between countries that easily recognized by $44.8 \%$ of respondents to the reason for choosing ecommerce. The second most reason is that it saves you time, and can shop without time constraints. Behind the facilities offered by online shopping, the system will certainly give effect, one of which is the decline of consumers who are interested in doing conventional selling (offline). Based on the results of the survey, as much as $56.7 \%$ more interested in shopping online and than conventional shopping. 


\title{
Model berbelanja apa yang lebih anda sukai
}

\author{
67 tanggapan
}

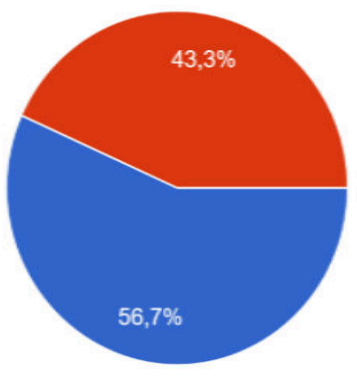

Online (E-commerce)

Konvensional (Offline)

Figure 7. The percentage of the choice of shopping method is most liked by the community.

All facilities in fulfilling the need to be one of the main reasons people prefer buying and selling methods with e-commerce compared to conventional methods. Based on the results of the survey in Figure 8, of several factors that became the reason for using e-commerce, 44.8\% of respondents assessed with e-commerce a wider product purchase. Besides, by utilizing ecommerce technology, respondents rate $37.3 \%$ can save time because the customer does not have to come to the store to choose and buy goods.

The use of e-commerce technology can include wider and borderless market share. People can enjoy searching for the desired item at any time and anywhere. Based on the results of a survey of 17 respondents assessed $25.4 \%$ of e-commerce facilities can be felt anytime during 24 hours/7 days.

\section{Jika Anda memilih e-commerce, alasan menggunakan e-commerce adalah} 67 tanggapan

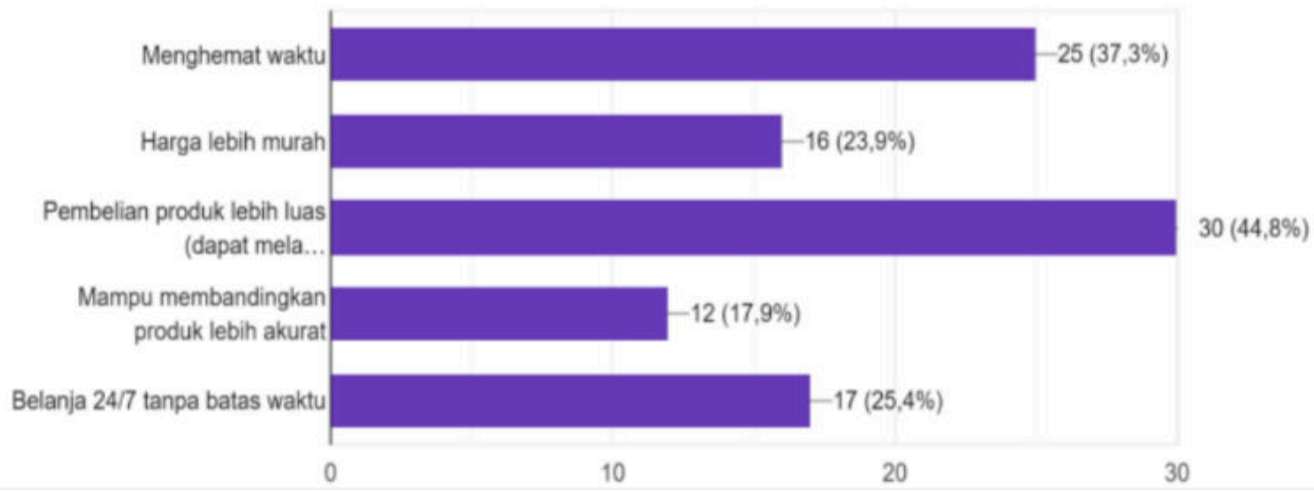

Figure 8. Percentage of community reasons to choose e-commerce. 
Closely related to the 4.0 Industrial Revolution and Society 5.0 against the changing behavior of economic societies. With the development of e-commerce technology, the community no longer needs to struggle in conducting transactions. One of the reasons for the release of Society 5.0 by Japan because of the year of the Japanese population is lacking in productive age. So many seniors who feel difficult to do various activities and meet the needs of. Therefore, by adopting the technological development and the needs of the Japanese people, the Japanese government launched the Society 5.0.

There is a lot of creativity from the young generation to conform to the development of the 4.0 Industrial Revolution and Society 5.0. SMEs in Indonesia is one of the government's shots to improve the Community economy. The Government has provided funds amounting to 3.2 trillion rupiahs to develop the SMEs in facing the Millennium Era. The role of government and the high interest of people to develop SMEs with the advancement of technology and community needs can be a drive of creativity and productivity of SMEs business people.

Besides, the role of the educational world is crucial in addressing the 4.0 Industrial Revolution and Society 5.0. The world of education as one of the science-generation printers must be able to adapt existing developments with the learning given. With these adjustments, Indonesia will still adjust the existing developments because it is supported by professionals.

\section{Conclusion}

The development of the 4.0 Industrial Revolution and Society 5.0 has given much impact on people's lives. Community behavior is more pleased with the utilization of technology to fulfill the needs with all facilities is one of the forms of the era of the Industrial Revolution and Society 5.0 in Indonesia. E-commerce is one of the technological developments in Indonesia that can easily fulfill the community. $44.8 \%$ of survey results show transactions with e-commerce more in demand because of wider market share, more convenience, without time limit and price comparison between products can be more accurate. But with the development, there is an important work of government, society, and the world of education so as not to dissolve with the existing developments. So that the social impact that will arise does not become a negative polemic among the community.

\section{References}

[1] A. Schütze, N. Helwig, and T. Schneider, "Sensors 4.0 - Smart Sensors and Measurement Technology Enable Industry 4.0,” J. Sensors Sens. Syst., vol. 7, no. 1, pp. 359-371, 2018.

[2] C. W. Sunarni and A. S. Ambarriani, "The Pricing Practices: Management Accounting Perspective," Rev. Integr. Bus. Econ. Res., vol. 8, no. 2, pp. 84-97, 2019.

[3] V. La et al., "Policy response, social media and science journalism for the sustainability of the public health system amid COVID-19 outbreak: The Vietnam lessons," Aisdl, pp. 1-35, 2020.

[4] I. Kemény, J. Simon, Á. Nagy, and K. Szucs, "Measuring Quality Perception in 
Electronic Commerce a Possible Segmentation in The Hungarian Market," Ind. Manag. Data Syst., vol. 116, no. 9, pp. 1946-1966, 2016.

[5] I. M. A. G. Azmi and J. C. Phuoc, "International Norms in Regulating e-Commerce: The Electronic Commerce Chapter of The Comprehensive Trans-Pacific Partnership Agreement," Int. J. Bus. Soc., vol. 21, no. S1, pp. 66-80, 2020.

[6] S. Bijakši, B. Marki, and A. Bevanda, "Expert Pricing System as Part of Marketing Mix," Informatologia, vol. 50, no. 3-4, pp. 141-150, 2017.

[7] K.-Y. Tang, C.-H. Hsiao, and M.-C. Chen, "A Research Survey of Electronic Commerce Innovation: Evidence from the Literature," Adv. Technol. Innov., vol. 4, no. 4, pp. 247-259, 2019.

[8] M. Pozvek, "Vat in Digital Electronic Commerce," InterEULawEast - J. Int. Eur. Law, Econ. Mark. Integr., vol. 4, no. 1, pp. 37-53, 2017.

[9] X. Xu, "Platform Licensing for Electronic Commerce Ecosystems," J. Electron. Commer. Res., vol. 18, no. 2, pp. 177-188, 2017.

[10] P. Maresova et al., "Consequences of Industry 4.0 in Business and Economics," Economies, vol. 6, no. 3, pp. 1-15, 2018.

[11] L. Melnyk, O. Kubatko, I. Dehtyarova, O. Matsenko, and O. Rozhko, "The Effect of Industrial Revolutions on The Transformation of Social and Economic Systems," Probl. Perspect. Manag., vol. 17, no. 4, pp. 381-391, 2019.

[12] M. Fawzy, Sharuddin, Rajagderan, and W. Zulkifly, "E-commerce Adoption and Analysis of the Popular E-commerce Business Sites in Malaysia," Bus. Econ. J., vol. 09, no. 02, pp. 1-11, 2018.

[13] E. V. Maslova, E. V. Kulchitskya, E. V. Melyakova, N. G. Kizyan, and O. S. Penzina, "Model of an organization's internal environment development on the basis of human resource audit," J. Adv. Res. Law Econ., vol. 8, no. 1, pp. 118-127, 2017.

[14] et al., "Method of Payment Adoption in Indonesia E-Commerce," Asian J. Technol. Manag., vol. 12, no. 2, pp. 94-102, 2019.A. Junita, E. Erlina, E. Abubakar, I. Muda, and S. Abdullah, "Influence of Budget Participation and Leadership Style Against Rebudgeting on Work Unit of Apparatus," J. Bus. Retail Manag. Res., vol. 13, no. 2, pp. 274-284, 2018.

[15] K. H. Wang and Y. C. Peng, "Electronic Commerce and Firm Performance: Evidence From the Taiwanese Industries," Int. J. Econ. Perspect., vol. 10, no. 1, pp. 14-26, 2016.

[16] N. K. L. A. Merkusiwati and I. G. A. E. Damayanthi, "Earnings Management and Different Tax Book To Explain Earnings Persistency," E-Jurnal Akunt., vol. 30, no. 1, p. 202, 2020.

[17] C. Conrad, R. Serlin, and M. Harwell, "Research Design in Qualitative Quantitative/Mixed Methods," in The SAGE Handbook for Research in Education: Pursuing Ideas as the Keystone of Exemplary Inquiry, 2014.

[18] D. E. McNabb, "Fundamentals of Quantitative Research," in Research Methods for Public Administration and Nonprofit Management, Fourth edi., New York: Routledge, 2017, pp. 111-121.

[19] Sugiyono, Metode Penelitian Kuantitatif, Kualitatif, dan R\&D. 2016.

[20] S. Yadav, "E-Commerce: The Rise and Rise of E-Commerce in India," Splint Int. J. Prof., vol. 3, no. 10, pp. 23-29, 2016. 